\title{
Critical Thinking Cultivation in Chinese College English Classes
}

\author{
Lili Zhang ${ }^{1,2} \&$ Sukwoo Kim ${ }^{1}$ \\ ${ }^{1}$ Department of Education, Pusan National University, Pusan, Republic of Korea \\ ${ }^{2}$ School of Languages and Media, Anhui University of Finance \& Economics, Bengbu, China \\ Correspondence: Lili Zhang, School of Languages and Media, Anhui University of Finance \& Economics, \\ Bengbu 233030, China. Tel: 86-138-6501-5298. E-mail: lilizhang2008@yeah.net
}

Received: June 9, 2018 Accepted: July 7, 2018 Online Published: July 9, 2018

doi: 10.5539/elt.v11n8p1 URL: http://doi.org/10.5539/elt.v11n8p1

\begin{abstract}
Through literature study of researches on critical thinking, this paper gives an analysis of the present situation and existing problems of critical thinking cultivation in Chinese college English classes, probes into the rationale for critical thinking cultivation and discusses how to cultivate students' critical thinking in Chinese college English class context through constructing constructive learning environment, designing flexible instructional strategies, and adopting formative, seamless assessment.
\end{abstract}

Keywords: critical thinking, cultivation, college English, China

\section{Introduction}

With skyrocketing development of this knowledge-based "information explosion" age, it is very important for people to discern information critically and then make effective utilization of the information. As one of the essential thinking skills, critical thinking enables people to improve themselves in ability of criticizing, questioning, evaluating, and reflecting. People have reached a widespread consensus that critical thinking is an indispensable tool for people to equip with in this rapidly-changing society (Dower, 2003) and is one of the five important skills that future citizens need to develop (Liu, 2000). Moreover, critical thinking has emerged as a hot issue at the forefront of higher education.

However, for a long time, there has been a missing of critical thinking cultivation in Chinese college English classes. The majority of college English teachers spend most of their time improving students' language competence while ignoring students' critical thinking cultivation, which results in students' "absence of critical thinking" (Huang 1998).

With advance of research in cognitive development, the close connection between language learning and thinking processes has been generally recognized by language teachers and linguists. Noticing that many language teaching approaches are unreflective in that they only encourage verbal output or passive input, Tarvin and Alarishi $(1991,1994)$ have suggested some approaches to making language teaching more thoughtful. In addition, from perspective of the current educational trends which promote higher-order thinking, Chamot (1995) has argued that EFL teachers should convert their classes into a "community of thinkers."

\section{Necessity for Critical Thinking Cultivation in Chinese College English Classes}

Critical thinking involves "rational judgment and discernment of the elements of reasoning and in contrast to rote memorization or simple information recall, methods for encouraging critical thinking have as their goal the stimulation of the analytical and evaluative processes of the mind" (Paul, 1992). Despite different interpretations of critical thinking, contemporary researchers agree that critical thinking is "purposeful, self-regulatory judgment which results in interpretation, analysis, evaluation, and inference, as well as explanation of the evidential, conceptual, methodological, criteria logical or contextual considerations upon which judgment is based" (Facione, 1990).

It has been argued that "learners from Asian cultures are less proficient in critical thinking because they are socialized to be empathetic and to conform" (Atkinson, 1997). Carson (1992) emphasizes the role that "rote learning and memorization play in Chinese students' learning strategies". In addition, Ballard and Clanchy (1991) describe "Asian students as reproductive, as opposed to analytical, learners", and "Chinese learners as passive, unquestioning, and lacking the ability to think critically". Their learning styles, similarly, have been 
characterized as "reproductive rather than analytical or speculative" (Shi, 2006).

\subsection{Resolving the Current Dilemma of College English Teachers and Students in China}

College English classes across China are in a state of crisis, which are characterized by "time-consuming but low-performing." There is abundant evidence that a large proportion of college English classes in China inadequately prepare students for the demands of work, and everyday living in real world. Reviews of recent researches on college English class teaching and exiting exams in China indicate that among those university graduates, far from enough students have acquired the necessary knowledge or abilities for workplace or life success. Competencies associated with specific higher-level cognitive processes, also as critical thinking, are identified as foremost among the deficits.

To cope with this problem, Ministry of Education of the People's Republic of China has put the goal of development of critical thinking skills into The College English Curriculum Requirements (The Requirements hereafter). The Requirements makes it clear the expectations for university students to improve their critical thinking skills. As stated in The Requirements, there are specific requirements of critical thinking skills for listening, speaking, reading and writing respectively (Department of Higher Education, Ministry of Education of the People's Republic of China, 2007).

However, in the meantime, college English teachers face many challenging tasks, the considerable one of which is "covering" the content matter which is identified by the state standards and on which their students will be tested. Research findings indicate that much of the mandated high-stakes testing have resulted in teachers' over-concentration on lower-order thinking skills. Previous studies suggest that "educating low-performing university students in college English classes and adhering to state-mandated curriculum may shortchange essential skills, such as critical thinking or the 'habits of mind'that students need for success in workplace and in their lives as responsible citizens" (Wang, 2011; Wen et al., 2009).

\subsection{Adjusting to Social Influences and Learning Process Accommodation}

In the world beyond classroom, university students can get access to proliferation of information through internet, but only those individuals with well-developed thinking skills can manage information effectively. "The vital need for critical thinking in and beyond formal learning in everyday life, relationships, ethical choices, and in the maintenance and development of participatory democracies grows increasingly apparent" (Halpern, 2003; Pithers, 2000).

Moreover, advancing critical thinking skills also contributes to realization of higher education's goal of building responsible citizens. In this increasingly complex society, individuals are required to make their judgments and decisions on basis of careful evaluation of evidence. "Coupled with expectations to make timely and oftentimes immediate decisions, this is especially salient given the exponential amount of available information and individuals' need to reflect on what they decide to believe or to do" (Renaud \& Murray, 2008). "Helping students cultivate higher-order cognitive skills, including critical thinking, can help individuals improve their functioning in multiple circumstances" (Tsui, 2002).

In addition, in the digital age, outside college English class, learning to become a strategic learner, who knows how to draw a vastly expanded world of information through internet, is significantly better than learning English simply through rote memorization. Unlike reference libraries and printed books, the sheer vastness of information related to English learning available online requires new skills at finding, sorting through, and evaluating information; rejecting extraneous material; validating information sources and resolving conflicting information; individual discipline and commitment (Clark \& Mayer, 2002). Accordingly, students must further develop and broaden such higher-order skills as critical thinking together with informed decision making, and real-world problem solving in this digital age.

\subsection{Improving Learners' Language Proficiency and Language Learning Efficiency}

As for "language as a way of thinking and learning", it has been more of a pedagogical catchphrase than instructional practice. Traditional approaches to language education such as grammar-based syllabus, functional-notional syllabus, and natural approach, etc. are criticized by the Thinking-Approach Project which was supported by the British Council in 2004, mainly for the key contradiction that language teachers spend most of their time teaching language skills instead of preparing students for life in real world. In addition, Kabilan (2000) argues that although the use of language as a communication tool is emphasized by the now popular communicative approach to language teaching, in practice this approach does not work well in helping students become proficient in the target language.

By using Cornell Critical Thinking Test, Rashid and Hashim (2008) carried out an investigation among 280 
undergraduates to explore the relationship between critical thinking and language proficiency. The result indicates that there is a significant correlation between critical thinking competence and language performance. Students with a sharp mind to think critically are more likely to learn and use English more flexibly and efficiently. Therefore, cultivation of critical thinking and the mastery of linguistic skills are not contradictory. Instead, critical thinking can improve students' language learning efficiency, build up their confidence in study and facilitate their learning process.

\section{Approaches to Critical Thinking Cultivation in Chinese College English Classes}

Importance of critical thinking cultivation has been widely acknowledged by researchers and educators around the world. Critical thinking cultivation can be "likened to Piaget's concrete and formal operations since stages of cognitive development are linked to intellectual potential and environmental experiences" (Ornstein \& Hunkins, 2009). Before students reach the formal operations stage their critical thinking ability is likely to be limited by their inability to handle abstract ideas. For this reason, learning environment plays a vital role in providing experiences for students to generate ideas.

\subsection{Constructing Constructive Learning Environment}

In traditional teaching context, large-group lecture is widely employed in college English teaching. The majority of students are passive in just receiving what the teachers teach with no active thinking about what they are learning. This kind of instructional practice estranges from the notion of "mastery learning" proposed by Bloom $(1974,1976)$, which requires the management of events that go beyond "giving of information" by the teacher. Hence, the process of critical thinking cultivation needs to provide students with opportunities to reflect, to explore, and to solve some practical problems in their learning, work, and daily lives.

At present, technologies, such as internet, and course management software have potential to change traditional lectures to lectures with class interaction, either synchronously or asynchronously. With computer-mediated communication systems, online education provides a potentially rich social learning environment, in which active leaning collaboration can be supported and facilitated (Brown, 1997). Discussions can be done among students in small groups, asynchronously, in a virtual workplace. Learner motivation and the skills needed for successful self-directed learning are greatly aided by implementation of engaging courseware strategies, such as online discussions, interactive games, animation and graphics, and stories or real-world scenarios.

College English teachers need to continually ensure that their students are aware that online learning courses will contribute to their personal development, which in turn will help to create an overall learning culture within their class that will drive intrinsic motivation in critical thinking cultivation (Masie, 2001). In addition, teachers' managerial participation in students' personal development plan will further drive and motivate students to acquire new skills as well as aid in increasing awareness and benefits of critical thinking cultivation in college English learning. If teachers encourage peer acceptance and support during online English learning, the drive to excel beyond one's peers will serve as an additional and very compelling motivator in critical thinking cultivation (Masie, 2001). By this way, college English teachers can help students with cultivation of critical thinking ability on basis of their cognition of their prior learning, internalize and assimilate what they have learned.

\subsection{Designing Flexible Instructional Strategies}

Cultivation of critical thinking competence is not confined to teaching learners how to foster critical thinking only. Instead, subtler and more acceptable ways of integrating critical thinking cultivation into teaching process should be encouraged, such as combination of critical thinking cultivation with teaching materials, classroom discussions, homework, extracurricular activities and examinations etc.

As for college English classes in China, optimally, "students need a learning environment that lets them work together on problems and produce, as a group, some kind of cohesive deliverable product, which might be in the form of a group plan, research project, report, or case study etc.” (Klemm, 1998). As a means of motivating, presenting problems or issues that capture students' interest and emotional involvement is suggested by Maier (1971). With this kind of objective, small groups have the chance to practice both communication skills and problem-solving strategies. Subject-matter mastery, attitude formation, and problem solving are often considerd as three kinds of appropriate objectives for critical thinking cultivation by group discussion (M. D. Gall \& J. P. Gall, 1976).

In addition, in critical thinking cultivation process, collaboration also works. To optimize collaboration, a context and a platform are indispensible, which can be provided well by blended learning (Golas, 2000). "Blended learning coupled with collaboration is a key combination for maximizing training investments, and for enhancing 
individual and group performance" (Bedinger, 2002). That is because learners can benefit from the freedom to browse and explore, to inquire and seek responses to their own questions rather than following a predetermined path of instruction when blended learning is built on their prior knowledge base (Oliver et al., 1996).

\subsection{Adopting Formative, Seamless Assessment}

During the process of critical thinking cultivation, assessment should become an integrated, ongoing, and seamless part. McLellan (1993) points out that "more reliable assessments can take the form of evaluation measures, such as portfolios, summary statistics of learners' paths through instructional materials, diagnosis, reflection, and self-assessments."

Besides, as for critical thinking cultivation assessment, Hiltz (1986) found that "time for reflection" works well in enhancing learning results. That is because reflective thoughts always generate critical thinking. Undesirably, this reflection practice is a void in many university students' learning experience in that they pay much attention to fulfilling their teachers' requirement but seldom or never reflect on their learning results, learning strategies or learning efficiency. Hence, teachers should take responsibility to guide students to develop regular reflections, to assess their learning experience, and to adjust their learning strategies.

By reflecting on their learning, students can gain more awareness of their strengths and weaknesses. This practice will help them in utilizing their advantages as well as breaking through their limitations. Learning through continuous reflection will certainly improve students' critical thinking skills. To help students reflect more effectively and hence facilitate critical thinking cultivation, suggested approaches for teachers include asking students to discuss their learning in small cooperative groups about their gains in learning and room for their future improvement. In addition, requirement of regular reflection paper will be of significant help.

\section{Conclusion}

At present, a nation-wide college English teaching reform is being implemented in China, which characterizes in a shift from teacher-centered teaching paradigm to student-oriented paradigm. Since this paradigm shift stresses cultivation of learners' comprehensive ability, innovative spirit, and ability, it provides a favorable context for critical thinking cultivation of college English learners. With deepening of this reform, the cultivation of learners' critical thinking will become an increasingly indispensable element in college English teaching process. Therefore, it is of high necessity for teachers to integrate cultivation of critical thinking into their daily teaching practice. Since learners' language learning efficiency, and competence in study, work and life can be promoted through critical thinking cultivation, teaching students how to think critically and teaching them how to learn effectively are equally important. In view of importance and necessity of developing learners' critical thinking competence, college English teachers need to pay high attention to it. Hopefully, more efforts on critical thinking cultivation in Chinese college English classes will bring more desirable outcomes to students' success in study, work, and life and contribute to success of college English reform in China.

\section{Acknowledgments}

This research is sponsored by Anhui University of Finance \& Economics "Empirical Study of Formative Assessment and Washback Effect on Business English Teaching" (acjyzd 201748) and "Entrepreneurship Curriculum Design for Business English Majors" (acjyyb2017124).

\section{References}

Atkinson, D. (1997). A critical approach to critical thinking in TESOL. TESOL Quarterly, 31(1), 71-94. https://doi.org/10.2307/3587975

Ballard, B., \& Clanchy, C. (1991). Teaching Students from Overseas. Melbourne: Longman Cheshire.

Bedinger, D. (2002). The evolving role of collaboration in e-Learning. Retrieved summer 2003 from:http://www.collaborate.com/publication/newsletter/publications_newsletter_jan03.html\#

Bloom, B. S. (1974). An introduction to mastery learning theory. In J. H. Block (Ed.), Schools, society and mastery learning. New York: Holt, Rinehart and Winston.

Bloom, B. S. (1976). Human characteristics and learning. New York: McGraw- Hill.

Brown, A. (1997). Designing for learning: What are the essential features of an effective online course? Australian Journal of Educational Technology, 13(2), 115-126. https://doi.org/10.14742/ajet.1926

Carson, J. (1992). Becoming biliterate: First language influences. Journal of Second Language Writing, 1(1), 37-60. https://doi.org/10.1016/1060-3743(92)90019-L

Chamot, A. (1995). Creating a community of thinkers in the ESL/EFL classroom. TESOL Matters, 5(5), 1-16. 
Clark, R. C., \& Mayer, R. E. (2002). e-learning and the science of instruction: Proven guidelines for consumers and designers of multimedia learning. New York: John Wiley.

Coker, P. C. (2009). The effects of an experiential learning program on the clinical reasoning and critical thinking skills of occupational therapy students (Doctoral dissertation).

Daud, N. M., \& Husin, Z. (2004). Developing critical thinking skills in computer-aided extended reading classes. $\begin{array}{lllll}\text { British Journal of Educational Technology, } & 35(4), & \text { 477-487. }\end{array}$ https://doi.org/10.1111/j.0007-1013.2004.00405.x

Department of Higher Education of Ministry of Education. (2007). College English curriculum requirements. Beijing: Foreign Language Teaching and Research Press.

Dower, N. (2003). An introduction to global citizenship. Edinburgh: Edinburgh University Press.

Gall, M. D., \& Gall, J. P. (1976). The discussion method. In N. L. Gage (Ed.), The psychology of teaching methods (Seventy-fifth Yearbook of the National Society for the Study of Education). Chicago: University of Chicago Press.

Golas, K. C. (2000). Guidelines for designing online learning. Proceedings of the Inter-service Industry Training and Education Systems Conference. FL: Orlando.

Halpern, D. F. (2003). Thought and knowledge: An introduction to critical thinking (4th ed.). Mahwah, NJ: Lawrence Erlbaum Associate.

Hiltz, S. R. (1986). The virtual classroom: Using computer mediated communication for university teaching. Journal of Communication, 36(2), 95-104. https://doi.org/10.1111/j.1460-2466.1986.tb01427.x

Huang Y. S. (1998). Absence of critical thinking. Foreign Languages and Teaching, (1), 1- 9.

Kabilan, M. K. (2000). Creative and critical thinking in language classrooms. The Internet TESL Journal, 6(6).

Klemm, W. R. (1998). Eight ways to get students more engaged in online conferences. T.H.E. Journal, 26(1), 62-64.

Lierman, J. (1997). Effects of instructional methods upon the development of critical thinking skills in baccalaureate nursing students (Unpublished doctoral dissertation). University of Missouri-Kansas City, Kansas City, America.

Liu, R. D. (2000). On the meaning and connotation of critical thinking. Teacher Education Research, (1), 56-61.

Maier, N. R. F. (1971). Innovation in education. American Psychologist, 26(8), 722-725. https://doi.org/10.1037/h0032126

MASIE Center (2001). $\quad$ Retrieved summer 2003 from http://www.masie.com/masie/researcherreports/ASTD-Exec-Summ.pdf

McLellan, H. (1993). Evaluation in a Situated Learning Environment. Educational Technology, 33(3), 39-45.

Oliver, R., Herrington, J., \& Omari, A. (1996). Creating effective instructional materials for the World Wide Web. Retrieved from http://elmo.scu.edu.au/sponsored/ausweb/ausweb96/educn/oliver/

Ornstein, A., \& Hunkins, F. (2009). Curriculum Design. In Curriculum: Foundations, Principles and Issues (5th ed.) (pp. 181-206). Boston, MA: Pearson/Allyn and Bacon.

Pithers, R. T., \& Soden, R. (2000). Critical thinking in education: A review. Educational Research, 42(3), 237-249. https://doi.org/10.1080/001318800440579

Rashid, R. A., \& Hashim, R. A. (2008). The Relationship between critical thinking and language proficiency of Malaysian undergraduates. Proceeding of the EDU-COM 2008 International Conference, Symposia and Campus Events. Edith Cowan University, Perth Western, Australia. Retrieved from $\mathrm{http} / /$ ro.ecu.edu.au/cgi/viewcontent.cgi?article $=1035 \&$ context $=$ ceducom

Renaud, R. D., \& Murray, H. G. (2008). A comparison of a subject-specific and a general measure of critical thinking. Thinking Skills and Creativity, 3(2), 85-93. https://doi.org/10.1016/j.tsc.2008.03.005

Shi, L. (2006). The successors to Confucianism or a new generation? A questionnaire study on Chinese students' culture of learning English. Language, Culture and Curriculum, 19(1), 122-147. https://doi.org/10.1080/07908310608668758

Tarvin, W., \& Al-arishi, A. (1991). Rethinking communicative language teaching: Reflection and the EFL classroom. TESOL Quarterly, 25(1), 9-27. https://doi.org/10.2307/3587026 
Tsui, L. (2002). Fostering critical thinking through effective pedagogy: Evidence from four institutional case studies. Journal of Higher Education, 73(6), 740-763. https://doi.org/10.1353/jhe.2002.0056

Wang, S. R. (2011). On the state of college English teaching in China and its future development. Foreign Languages in China, (5), 4-11, 17.

Wen, Q. F., Wang, J. Q., Zhao, C. H., Liu, Y. P., \& Wang, H. M. (2009). On the construction of the conceptual framework for accessing Chinese undergraduates' critical thinking skills. Foreign Language World, (1), $37-43$.

\section{Copyrights}

Copyright for this article is retained by the author(s), with first publication rights granted to the journal.

This is an open-access article distributed under the terms and conditions of the Creative Commons Attribution license (http://creativecommons.org/licenses/by/4.0/). 